\title{
EXAMINING PREDICTIVE FACTORS OF THE STUDENT MIDWIVES' ATTITUDES AND BELIEFS ABOUT SEXUALITY DURING PREGNANCY WITHIN THE FRAMEWORK OF SEXUAL COUNSELING
}

\author{
Öğrenci Ebelerin Gebelikte Cinsellik Konusundaki Tutum ve \\ İnançlarını Yordayıcı Faktörlerin Cinsel Danışmanlık Çerçevesinde İncelenmesi
}

Burcu AVCIBAY VURGEÇ ${ }^{1}$, Şule GÖKYILDIZ SÜRÜcÜ1 ${ }^{(D)}$

\begin{abstract}
Pregnant women and their partners are especially vulnerable to the long-term decrease in sexual activity due to pregnancy-related symptoms and/or negative beliefs and attitudes affecting sexuality. In this regard sexual consultation and attitudes of consultant about sexuality are an important point for especially midwives. This study aims to examine predictive factors of the student midwives' attitudes and beliefs about sexuality during pregnancy within the framework of sexual counseling role. The study was designed as a cross-sectional and descriptive web based survey. The study was conducted with 365 undergraduate midwifery students enrolled in a public university. Student midwives had medium-level negative attitudes and beliefs about sexuality during pregnancy. The presence of the attitudes and beliefs about sexuality during pregnancy was found to be associated with sexual counseling comfort $(p<0.01)$. Regression models showed that having adequate knowledge about sexual counseling, experience of presenting this knowledge, cultural doctrines, sexual information topics and time of initiating counseling were effective predictors of the decrease in negative attitudes and beliefs in sexuality during pregnancy $(R=0.196-0.361, p<0.01)$. Findings showed that individual attitudes and beliefs during pregnancy can affect counseling skills and content.

Keywords: Sexuality, pregnancy, sexual beliefs, midwife, sexual counseling.
\end{abstract}

\section{özet}

Gebe kadınlar ve eşleri, gebelikle ilgili semptomlar ve/veya cinselliği etkileyen olumsuz inanç ve tutumlar nedeniyle, özellikle cinsel aktivitede uzun vadeli azalmaya karşı savunmasızdırlar. Bu bakımdan cinsel danışmanlık ve danışmanın cinselikle ilgili tutumları özellikle ebeler için önemli bir noktadır. Bu araştırmada ebelerin gebelikte cinselliğe ilişkin tutum ve inançlarının yordayıcı faktörlerinin cinsel danışmanlık rolü çerçevesinde incelenmesi amaçlanmıştır. Çalışma, Türkiye'de bir devlet üniversitesine kayıtlı 365 lisans ebelik öğrencisi ile yapılmıştır. Öğrenci ebeler, gebelikte cinsellikle ilgili orta düzeyde olumsuz tutum ve inançlara sahiptir. Gebelikte cinsellikle ilgili tutum ve inançların varlığı, cinsel danışmanlık konforu ile ilişkili bulunmuştur $(p<0,01)$. Regresyon modelleri, cinsel danışmanlık hakkında yeterli bilgiye sahip olmanın, bu bilgiyi sunma deneyiminin, kültürel doktrinlerin, cinsel danışmanlık konularının ve danışmanlığa başlama zamanının, gebelikte cinselliğe yönelik olumsuz tutum ve inançlardaki azalmanın etkili yordayıcıları olduğunu göstermiştir $(R=0,196-0,361, p<0,01)$. Bulgular, bireysel cinsel tutum ve inançların danışmanlık becerilerini ve içeriğini etkileyebileceğini göstermiştir.

Anahtar kelimeler: Cinsellik, gebelik, cinsel inançlar, ebe, cinsel danışmanlık.

1- Cukurova University, Faculty of Health Science, Department of Midwifery, Cukurova, Turkey

Sorumlu Yazar / Corresponding Author: Dr. Öğr. Üyesi Burcu AVCIBAY VURGEÇ

e-posta / e-mail: burcuavcibay@hotmail.com

Geliş tarihi / Received: 08.02.2021, Kabul Tarihi / Accepted: 11.04.2021

ORCID: Burcu AVCIBAY VURGEÇ: 0000-0003-2467-5101

Şule GÖKYILDIZ SÜRÜCÜ: 0000-0002-0088-4219

Nasıl Atıf Yaparım / How to Cite: Avcıbay Vurgec B, Gokyildiz Surucu S. Examining predictive factors of the student midwives' attitudes and beliefs about sexuality during pregnancy within the framework of sexual counseling. ESTUDAM Public Health Journal. 2021;6(2):93-104. 


\section{Introduction}

Sexuality is a concept that has been in the center of being humans throughout life, and it encompasses the concepts of gender, gender identities and roles, sexual orientation, erotism, desire, sexual intercourse, and reproduction. This multidimensional concept is experienced and expressed in relationships through thoughts, fantasies, desires, beliefs, attitudes, values, behaviors, practices, and roles. Although sexuality encompasses all of these aspects, not all of them are experienced or expressed all the time because the interaction of many external factors such as biological, psychological, social, economic, political, cultural, ethical, legal, historical, religious and moral issues is involved (1).

Beside physical and hormonal changes, pregnancy is a process that involves many psychological changes and affects women's life in radical ways. Given these changes, pregnancy is a very sensitive period which is frequently accompanied by the changes in couples' sexual life (2). Although the changes in the sexual partner inherently cause no problems, long pauses in sexual activity have the potential to affect intimate relationships because they are associated with sexual satisfaction and sexual frequency (3). All relationships have ebbs and flows in the frequency of sexual activities. However, pregnant women and their partners are especially vulnerable to the long-term decrease in sexual activity due to pregnancy-related symptoms and/or negative beliefs and attitudes affecting sexuality (4-7). Various sociological and psychological behavioral theories support the effects of these beliefs and attitudes on behaviors. These theories suggest that individuals who demonstrate fewer negative attitudes toward sexual intercourse during pregnancy could avoid sexual behaviors during pregnancy (8). Although the worries caused by the negative attitudes and beliefs associated with the individual's culture are groundless, an intercultural common cause of giving up sexual activity has been defined $(4,5,7,9-12)$.
Negative attitudes and beliefs about sexual activity during pregnancy generally focus on its negative effects on pregnancy and fetal health. Miscarriage, harm to the fetus, preterm birth, infection, and rupture of membranes seem to be common causes in many cultures $(5-7,13)$. Although they are less common, sexual activity is limited due to reasons which include "fetus could be exposed to sperms", "fetus might become blind or disabled", or even "the hymen of the female fetus might be harmed" (14). Therefore, effective sexual counseling by health professionals is an expected initiation to deal with these problems.

Although the assessment of attitudes and beliefs of pregnant women is important, an investigation of especially health professionals providing healthcare services to pregnant women about sexual attitudes and beliefs within the framework of sexual counseling is significant. Sexuality is accepted as an important area and a priority for research for nursing and midwifery (15, 16). There is no doubt that a person to provide counseling has his/her values and experiences. These values might affect the attitudes towards sexual problems, and negative attitudes may prevent effective health consultations (17). Therefore, an evaluation of students' knowledge about their own values, prejudices, and attitudes towards working on sexual health as well as awareness about their competence in approaching the problems are topics that should be investigated at the education phase (18-20). In this regard, identification of the attitudes and beliefs and the associated factors of midwives, who receive undergraduate education yet, about sexuality during pregnancy could bring the opportunity to prevent any negative reflections on their work-life after graduation. The aim of this study was examine predictive factors of the student midwives' attitudes and beliefs about sexuality during pregnancy within the framework of sexual counseling role. 


\section{Study Design and Setting}

This study was designed as a cross-sectional and descriptive one and conducted in the Faculty of Health Sciences of a public university. A web-based data collection was performed between 15th and 20 th of June 2020. The target population was all the students enrolled in the midwifery department where the researchers worked as lecturers. The Faculty of Health Sciences has two departments that provide undergraduate education in midwifery and nursing. The purposeful sampling method was utilized in line with the purpose of the study; hence, only the midwifery students were invited to participate in the study. There are 365 undergraduate students enrolled in the midwifery department. Except for 12 students who participated in the pilot study for the questionnaire and 8 students who did not want to participate in the study, the majority of the population was accessed. The study was completed with 345 (94.5\% of the target population) students who agreed to participate in the study. The midwifery department provides a four-year education at the undergraduate level, and the classrooms are homogenous in terms of the number of students.

\section{Data Collection}

Ethical permission was obtained from the Non-invasive Clinical Research Ethics Committee of Medical Faculty of the Cukurova University (Approval number: 2020/100-38). Data collection was performed online. All the data, which were quantitative in nature, were collected through a web-based questionnaire form within a period determined beforehand. Data were collected in four phases according to the class levels. Firstly, an invitation form to participate in the study was sent to students' emails. The students who were guided to the link saw the informed consent part. The participants who approved the consent part moved to the phase of filling in the questionnaire. Completing the online form took about 5 minutes.

\section{Data Collection Tools}

The online questionnaire form was composed of three parts. While the first part included questions about the socio-demographic features, the second part included the Sexuality Attitudes and Beliefs Survey used for identifying attitudes about sexual counseling, and the third part included the Attitudes and Beliefs Scale about Sexuality during Pregnancy used for assessing the sexual attitudes and beliefs during pregnancy.

Personal Data Form: The first part of the socio-demographic form included questions about descriptive characteristics such as age, class level, and marital status. The second part included factors that might have effects on individuals' sexual attitudes and behaviors and comfort level while providing sexual counseling. This section included 16 questions formed based on the study fields and counseling topics of midwives. These questions were formed in line with the purpose of the study, and no reliability and validity were performed. However, the questions were revised based on the comments provided by two faculty members from the Midwifery department, two mentors working in student clinic education, and an academic/psychologist. The questionnaire form was piloted with three students from each class level, 12 students in total. The final version was formed based on the feedback provided by these students.

Attitudes and Beliefs Scale about Sexuality during Pregnancy (ABSSP): ABSSP developed by Salcan and Gökyıldız Sürücü (21) is composed of 25 items responded on a 5-point Likert scale (1- I totally disagree to 5-I totally agree). There are no items that are scored reversely, and the scale has 4 subscales as follows: "Pregnancy and Sexuality" (item 1,2,3,4,5), "Concerns about the Baby" (item 6, 9, 10,12, 14, 15 and 16), "Sexuality/Attraction" (item 7 , 8, 11, 13 and 20) and "Concerns about the Pregnancy" (item 17, 18, 19, 21, 22, 23, 24 and 25). The ABSSP total score ranges from 25 to 125 points. Higher scores obtained 
from the scale indicate more negative attitudes and beliefs about sexuality during pregnancy. In their study conducted with pregnant women, Salcan and Gökyıldız Sürücü (2020) reported the cronbach's alpha internal consistency coefficient is 0.94 . This study conducted with students found the cronbach's alpha internal consistency coefficient as 0.92 .

Sexuality Attitudes and Beliefs Survey (SABS):SABS was developed by Reynolds and Magnan (22) and the Turkish reliability and validity of the scale were performed by Ayhan et al. (23). The scale is composed of 12 items responded on a 6-point Likert scale. Six out of 12 items in the scale were scored reversely to prevent bias (items 1, 2, 4, 6, 8, 10, 12 are scored reversely). The scores to be obtained from the scale range between 12 and 72 . Higher scores in the total scale score and item scores indicate increased negative attitudes and beliefs about sexual care. After the calculation of the reverse items, the statements in the scale can be converted to dichotomy data in line with the recommendations by Reynolds and Magnan (2005) by calculating the statements scored as (1), (2) and (3) as "I agree" and (4), (5) and (6) as "I disagree".

\section{Results}

The average age of the students was $20.56 \pm 1.59$ (min-max:18-30), and 99.7\% were single. When the students were asked to indicate the sources that helped them to form general attitudes toward sexuality, $74.2 \%$ stated that the information obtained from books, friends, and the internet were effective. The percentage of those who reported to have enough knowledge about sexual health and sexual counseling was $54.2 \%$. While $34.8 \%$ encountered pregnant women who required sexual counseling, $33.9 \%$ would provide information without any requirements. Almost half of the students reported to prefer providing counseling to

\section{Data Analyses}

Data were analyzed using the Statistical Program for Social Science 20.0 (SPSS) using descriptive and parametric statistical analysis methods. Initially, students' descriptive features, attitudes, and beliefs about sexuality during pregnancy, attitudes, and comfort levels during sexual consultancy and the affecting factors were analyzed descriptively. These analyses were determined as frequencies and percentages. Secondly, the Shapiro-Wilk W test was utilized to find out if the data distributed normally. The data distributed normally $(p<0.05)$. The comparison of the dependent and independent variables included Student's t-test for the comparison of 2 groups and One-way ANOVA for the differences between the comparisons of the mean scores of three or more groups. Pearson correlation test was used to identify the relationship between ABSSP and SABS with each other. Multiple Linear Regression analysis was utilized for the identification of the relationship between the dependent and independent variables with each other. Regression analysis results were demonstrated as regression coefficient $(\beta)$, coefficient of determination (R/R2), and goodness of fit the model ( $F$ and $p$ ) values. Statistical significance was taken as $p<0.05$.

couples at the same time. The majority of the participating students $(79.7 \%)$ stated that midwives/nurses were the most appropriate health professionals to provide counseling services about sexuality (Table 1).

The SABS mean score was $31.41 \pm 7.13$, and the ABSSP mean score was 44.97 \pm 14.29 . ABSSP and SABS scores decrease with the increase in students' age, sexual counseling knowledge level, the experience of providing counseling without the pregnant woman's request, and knowledge about continuing sexuality during pregnancy $(p<0.05)$. 
Table 1: Comparison of students' socio-demographic features and sexual counseling knowledge with ABSSP and SABS.

\begin{tabular}{|c|c|c|c|c|}
\hline Variables & $\mathrm{n}(\%)$ & $\begin{array}{l}\text { ABSSP } \\
\text { Mean }\end{array}$ & $\begin{array}{l}\text { SABS } \\
\text { Mean }\end{array}$ & $t / F-p$ \\
\hline \multicolumn{5}{|l|}{ Age } \\
\hline$\geq 20$ & $139(40.3)$ & $50.31 \pm 16.09$ & $32.68 \pm 7.49$ & $5.979-<0.001^{\mathrm{a}}$ \\
\hline$\leq 21$ & 206(59.7) & $41.37 \pm 11.66$ & $30.55 \pm 6.76$ & $2.73-<0.001^{b}$ \\
\hline \multicolumn{5}{|l|}{ Year of midwifery education } \\
\hline $1 s t$ & $87(25.2)$ & $52.41 \pm 16.42$ & $32.05 \pm 7.18$ & \multirow{4}{*}{$\begin{array}{r}15.061-<0.001^{a} \\
0.511-0.675^{b}\end{array}$} \\
\hline $2 n d$ & $92(26.7)$ & $45.97 \pm 14.20$ & $31.30 \pm 8.45$ & \\
\hline $3 r d$ & $77(22.3)$ & $40.14 \pm 11.53$ & $31.58 \pm 5.84$ & \\
\hline 4th & $89(25.8)$ & $40.84 \pm 10.87$ & $30.74 \pm 6.64$ & \\
\hline \multicolumn{5}{|l|}{$\begin{array}{l}\text { Level of knowledge about sexual health } \\
\text { and counseling }\end{array}$} \\
\hline I have no knowledge & $23(6.7)$ & $51.91 \pm 17.45$ & $36.74 \pm 7.93$ & \multirow{4}{*}{$\begin{array}{l}6.564-<0.001^{a} \\
7.142-<0.001^{b}\end{array}$} \\
\hline I have very little knowledge & $106(30.7)$ & $47.67 \pm 14.24$ & $32.48 \pm 6.71$ & \\
\hline I have sufficient knowledge & $187(54.2)$ & $43.77 \pm 13.75$ & $30.34 \pm 6.98$ & \\
\hline I have a lot of knowledge & $29(8.4)$ & $37.34 \pm 10.76$ & $30.14 \pm 6.78$ & \\
\hline \multicolumn{5}{|l|}{$\begin{array}{l}\text { Encountering pregnant women who } \\
\text { required sexual counseling }\end{array}$} \\
\hline None & $225(65.2)$ & $46.62 \pm 14.17$ & $31.80 \pm 7.57$ & \multirow{3}{*}{$\begin{array}{l}4.408-0.013^{\mathrm{a}} \\
1.150-0.318^{\mathrm{b}}\end{array}$} \\
\hline A few pregnant women & $108(31.3)$ & $41.78 \pm 13.37$ & $30.79 \pm 6.00$ & \\
\hline Many pregnant women & $12(3.5)$ & $42.83 \pm 19.92$ & $29.58 \pm 7.84$ & \\
\hline \multicolumn{5}{|l|}{$\begin{array}{l}\text { Providing sexual counseling without the } \\
\text { pregnant woman's request }\end{array}$} \\
\hline Yes & $117(33.9)$ & $41.90 \pm 13.09$ & $30.15 \pm 6.53$ & \multirow{2}{*}{$\begin{array}{l}-2.862-0.004^{a} \\
-2.356-0.019^{b}\end{array}$} \\
\hline No & $228(66.1)$ & $46.55 \pm 14.65$ & $32.05 \pm 7.35$ & \\
\hline \multicolumn{5}{|l|}{$\begin{array}{l}\text { Thoughts about continuing sexuality } \\
\text { during pregnancy }\end{array}$} \\
\hline It can continue in all conditions & $7(2.0)$ & $42.00 \pm 15.57$ & $32.00 \pm 9.34$ & \multirow{4}{*}{$\begin{array}{l}18.169-<0.001^{\mathrm{a}} \\
4.732-0.003^{\mathrm{b}}\end{array}$} \\
\hline Unless there is a medical problem & $296(85.8)$ & $43.05 \pm 13.10$ & $30.86 \pm 6.88$ & \\
\hline It is wrong in all conditions & $20(5.8)$ & $61.50 \pm 13.55$ & $34.35 \pm 7.46$ & \\
\hline I am not sure & $22(6.4)$ & $56.77 \pm 15.45$ & $35.86 \pm .7 .64$ & \\
\hline \multicolumn{5}{|l|}{$\begin{array}{l}\text { Health professionals suitable for providing } \\
\text { pregnant women with sexual counseling }\end{array}$} \\
\hline Midwife, nurse & $275(79.7)$ & $44.67 \pm 14.26$ & $30.82 \pm 7.02$ & \multirow{4}{*}{$\begin{array}{l}1.349-0.258^{a} \\
3.920-0.009^{b}\end{array}$} \\
\hline Doctor & $31(9.0)$ & $42.71 \pm 13.00$ & $32.84 \pm 7.50$ & \\
\hline Psychologist, therapist & $8(2.3)$ & $50.88 \pm 15.28$ & $37.13 \pm 7.25$ & \\
\hline I am not sure & $31(9.0)$ & $48.39 \pm 15.25$ & $33.71 \pm 6.71$ & \\
\hline \multicolumn{5}{|l|}{$\begin{array}{l}\text { Type of initiating sexual counseling to } \\
\text { pregnant women }\end{array}$} \\
\hline I wait for the pregnant woman to ask for it & $39(11.3)$ & $47.87 \pm 16.57$ & $36.03 \pm 7.09$ & \multirow{3}{*}{$\begin{aligned} 7.804- & <0.001^{\mathrm{a}} \\
18.189- & <0.001^{\mathrm{b}}\end{aligned}$} \\
\hline $\begin{array}{l}\text { The pregnant woman might feel shy, I do not } \\
\text { wait for her request }\end{array}$ & $91(26.4)$ & $49.16 \pm 14.46$ & $33.22 \pm 6.58$ & \\
\hline $\begin{array}{l}\text { I provide sexual counseling to all pregnant } \\
\text { women in a standard way, without any } \\
\text { requests }\end{array}$ & $215(62.3)$ & $42.67 \pm 13.31$ & $29.80 \pm 6.83$ & \\
\hline
\end{tabular}

a: $p$ value for ABSSP, b: $p$ value for $S A B S$

The difference in the class levels was significant only with ABSSP $(p<0.001)$. The difference between the health professional preference for providing pregnant women with sexual consultancy services was significant only with the SABS scores $(p<0.05)$ (Table 1). The ABSSP scores were found to increase significantly with the increase in the presence of the effects of the knowledge about sexuality acquired from the family, attitudes about expressing others' experiences to pregnant women, and the beliefs about sexual life $(p<0.05)$. The difference between the emotions felt by the pregnant woman in the case of sexuality counseling request and SABS scores was significant $(p<0.001)$ (Table 2$)$.

The scales that assessed the 
relationship of the scales with each other through the Pearson correlation test showed that the ABSSP and SABS were positively and significantly associated in terms of total scores and sub-scales. A medium-level relationship was found in terms of the total scores $(r: 0.359, p<0.001)$. SABS and Pregnancy and Sexuality $(r: 0.612, p<0.001)$, Concerns about the Baby $(r: 0.894, p<0.001)$,
Sexuality/Attraction $\quad(r: 0.749, \quad p<0.001)$, Concerns about the Pregnancy $(r: 0.886$, $p<0.001)$ sub-scales of the ABSSP had a positive, stronger association. These results indicate that the increase in the negative attitudes and beliefs about sexuality during pregnancy also increases the level of discomfort in counseling.

Table 2: Comparison of students' sexuality and sexual counseling attitudes with ABSSP and SABS.

\begin{tabular}{|c|c|c|c|c|}
\hline Variables & $\mathrm{n}(\%)$ & $\begin{array}{l}\text { ABSSP } \\
\text { Mean }\end{array}$ & $\begin{array}{l}\text { SABS } \\
\text { Mean }\end{array}$ & $\mathbf{p}$ \\
\hline \multicolumn{5}{|l|}{ Factors effective in the formation of sexual attitudes } \\
\hline Knowledge gained from the family & $32(9.3)$ & $51.88 \pm 18.85$ & $33.38 \pm 8.05$ & \\
\hline One's own sexual life experiences & $8(2.3)$ & $48.13 \pm 18.80$ & $28.63 \pm 6.76$ & $0.010^{\mathrm{a}}$ \\
\hline Sources of knowledge & $256(74.2)$ & $43.46 \pm 12.87$ & $31.06 \pm 6.98$ & $0.270^{\mathrm{b}}$ \\
\hline Religious Beliefs & $20(5.8)$ & $46.20 \pm 15.93$ & $32.40 \pm 6.44$ & \\
\hline Cultural dichotomies & $29(8.4)$ & $49.00 \pm 15.78$ & $32.38 \pm 7.76$ & \\
\hline \multicolumn{5}{|l|}{ Knowledge content transferred regarding sexuality } \\
\hline Always theoretical information & $229(66.4)$ & $43.14 \pm 12.80$ & $30.85 \pm 7.02$ & \\
\hline Generally, my own experiences & $49(14.2)$ & $43.71 \pm 14.08$ & $30.61 \pm 7.15$ & $<0.001^{a}$ \\
\hline No experiences, generally others' experiences & $56(16.2)$ & $53.16 \pm 16.52$ & $33.66 \pm 7.11$ & $0.013^{b}$ \\
\hline Always my/others' experiences & $11(3.2)$ & $47.00 \pm 19.22$ & $35.18 \pm 6.89$ & \\
\hline \multicolumn{5}{|l|}{$\begin{array}{l}\text { Emotions felt in case the pregnant woman requests } \\
\text { sexual counseling }\end{array}$} \\
\hline Embarrassment, shyness & $24(7.0)$ & $46.92 \pm 15.12$ & $38.38 \pm 6.38$ & \\
\hline Astonishment & $8(2.3)$ & $49.00 \pm 15.81$ & $38.75 \pm 3.95$ & $0.260^{\mathrm{a}}$ \\
\hline Finding it needless & $4(1.2)$ & $57.75 \pm 16.21$ & $37.25 \pm 6.65$ & $<0,001^{b}$ \\
\hline Discomfort & $6(1.7)$ & $49.50 \pm 19.61$ & $35.67 \pm 3.67$ & \\
\hline Comfort & $303(87.8)$ & $44.45 \pm 14.03$ & $30.50 \pm 6.84$ & \\
\hline \multicolumn{5}{|l|}{$\begin{array}{l}\text { Individual to be provided with counseling about } \\
\text { sexuality during pregnancy }\end{array}$} \\
\hline Only the pregnant woman & $94(27.2)$ & $47.12 \pm 14.97$ & $34.87 \pm 6.13$ & $0.203^{\mathrm{a}}$ \\
\hline Both couples at the same time & 204(59.1) & $43.94 \pm 13.80$ & $29.70 \pm 7.17$ & $<0.001^{\mathrm{b}}$ \\
\hline Both couples but at separate times & $47(13.6)$ & $45.17 \pm 14.78$ & $31.91 \pm 6.30$ & \\
\hline \multicolumn{5}{|l|}{ Beliefs about sexual life during pregnancy } \\
\hline Yes & $51(14.8)$ & $51.82 \pm 16.28$ & $32.33 \pm 7.24$ & $<0.001^{\mathrm{a}}$ \\
\hline No & $294(85.2)$ & $43.78 \pm 13.60$ & $31.25 \pm 7.11$ & $0.317^{\mathbf{b}}$ \\
\hline \multicolumn{5}{|l|}{ Personal comfort during sexual counseling } \\
\hline I worry about thoughts that it reflects my own sexual life & $26(7.5)$ & $49.27 \pm 13.88$ & $36.12 \pm 6.53$ & \\
\hline $\begin{array}{l}\text { I am not disturbed by the thoughts that it reflects my own } \\
\text { sexual life; the pregnant woman trust my }\end{array}$ & $101(29.3)$ & $45.79 \pm 15.76$ & $30.11 \pm 7.10$ & $<0.001^{a}$ \\
\hline recommendations more this way & & & & $<0.001^{b}$ \\
\hline $\begin{array}{l}\text { I do not think that it reflects my own sexual life, I am } \\
\text { quite comfortable }\end{array}$ & $158(45.8)$ & $41.84 \pm 12.20$ & $29.78 \pm 6.48$ & \\
\hline $\begin{array}{l}\text { My marital status is an important factor for my sexual } \\
\text { counseling comfort. }\end{array}$ & $60(17.4)$ & $49.98 \pm 15.18$ & $35.83 \pm 6.44$ & \\
\hline
\end{tabular}

The factors were analyzed with multiple linear regression analysis in 5 groups that included factors forming the attitudes, counseling experience, counseling attitudes, topics of counseling, and feeling comfortable about counseling. The model analyzed the relationship of the factors under these titles with ABSSP. Sources of knowledge in the factors shaping the attitudes were excluded from the model due to multicollinearity. Knowledge gained from the family and cultural doctrines among the factors shaping the attitudes were found to be negative, significant predictors of sexual attitudes and beliefs during pregnancy. This finding indicates that a positive increase is 
expected in the attitudes and beliefs about sexuality with a decrease in the tendency to family and cultural doctrines. The knowledge level in the counseling experience was found to be a negative, significant indicator of the sexual attitudes and beliefs during pregnancy. A decrease was found in attitudes and beliefs with the increase in the knowledge level. The view indicating that sexuality could continue during pregnancy in the counseling attitudes was the positive predictor of ABSSP, and a lack of beliefs about sexual life was the negative predictor of ABSSP. While having the view that sexuality could continue during pregnancy shows a decrease in negative attitudes and beliefs, there seems to be an increase in the negative attitudes and beliefs during pregnancy in the presence of beliefs about sexuality during pregnancy. The topics such as sexuality and sexual positions according to the trimesters were the predictors of negative attitudes and beliefs. Those who reported to be uncomfortable while they were giving information about these issues were found to have an increase in their negative attitudes and beliefs during pregnancy. As for feeling comfortable while providing counseling, the increase in the level of providing counseling to each individual in a standard way without individuals' requests has a negative effect in a way to decrease negative attitudes and beliefs (Table 3 ).

Table 3: Multiple linear regression analysis model of the predicting factors of ABSSP.

\begin{tabular}{|c|c|c|c|c|c|c|c|}
\hline \multirow{2}{*}{ Variable } & \multirow{2}{*}{ B } & \multirow{2}{*}{ SE } & \multirow{2}{*}{$\boldsymbol{\beta}$} & \multirow{2}{*}{$\mathbf{t}$} & \multirow{2}{*}{$\mathbf{p}$} & \multicolumn{2}{|c|}{ Model Summary } \\
\hline & & & & & & $\mathbf{R} / \mathbf{R}^{2}$ & $F / p$ \\
\hline \multicolumn{8}{|l|}{ Resources affecting attitudes } \\
\hline Information from the family & -8.418 & 2.644 & 0.171 & 3.184 & 0.002 & \multirow{4}{*}{$\begin{array}{l}0.196 \\
0.038\end{array}$} & \multirow{4}{*}{$\begin{array}{l}F=3.386 \\
p=0.010\end{array}$} \\
\hline Individual sexual life experiences & -4.668 & 5.062 & 0.049 & 0.922 & 0.357 & & \\
\hline Religious beliefs & -2.743 & 3.273 & 0.045 & 0.838 & 0.403 & & \\
\hline Cultural doctrines & -5.543 & 2.762 & 0.108 & 2.007 & 0.046 & & \\
\hline \multicolumn{8}{|l|}{ Sexual Counseling Experience } \\
\hline Counseling knowledge level & -3.798 & 1.097 & -0.194 & -3.461 & 0.001 & \multirow{4}{*}{$\begin{array}{l}R=0.254 \\
R^{2}=0.065\end{array}$} & \multirow{4}{*}{$\begin{array}{l}F=5.8684 \\
p<0.001\end{array}$} \\
\hline Encountering pregnant women & -1.209 & 1.598 & -0.047 & -0.757 & 0.457 & & \\
\hline $\begin{array}{l}\text { asking for counseling } \\
\text { Providing the pregnant woman with } \\
\text { sexual counseling without her } \\
\text { request }\end{array}$ & 2.238 & 1.850 & 0.074 & 1.210 & 0.245 & & \\
\hline $\begin{array}{l}\text { Health professional to provide } \\
\text { counseling }\end{array}$ & 0.643 & 0.832 & 0.041 & 0.772 & 0.441 & & \\
\hline \multicolumn{8}{|l|}{ Sexual Counseling Attitudes } \\
\hline $\begin{array}{l}\text { Emotions experienced in case of } \\
\text { information request }\end{array}$ & -0.731 & 0.652 & -0.057 & -1.120 & 0.264 & \multirow{4}{*}{$\begin{array}{l}R=0.361 \\
R^{2}=0.130\end{array}$} & \multirow{4}{*}{$\begin{array}{l}F=12.720 \\
p<0.001\end{array}$} \\
\hline $\begin{array}{l}\text { The person to be provided } \\
\text { counseling } \\
\text { The idea of continuing sexuality }\end{array}$ & -1.412 & 1.166 & -0.062 & -1.212 & 0.226 & & \\
\hline during pregnancy & 7.383 & 1.332 & 0.286 & 5.544 & $<0.001$ & & \\
\hline $\begin{array}{l}\text { Having beliefs about sexuality } \\
\text { during pregnancy }\end{array}$ & -6.145 & 2.080 & -0.153 & -2.954 & 0.003 & & \\
\hline \multicolumn{8}{|l|}{ Information topics } \\
\hline Sexuality according to trimesters & -9.063 & 4.566 & -0.150 & -1.985 & 0.048 & \multirow{8}{*}{$\begin{array}{l}R=0.218 \\
R^{2}=0.048\end{array}$} & \multirow{8}{*}{$\begin{array}{l}F=2.096 \\
p=0.036\end{array}$} \\
\hline $\begin{array}{l}\text { Sexual problems according to } \\
\text { trimesters }\end{array}$ & 2.587 & 5.023 & 0.038 & 0.515 & 0.607 & & \\
\hline $\begin{array}{l}\text { Conditions of sexual restrictions } \\
\text { during pregnancy }\end{array}$ & -0.779 & 4.278 & -0.011 & -0.182 & 0.856 & & \\
\hline Sexual positions during pregnancy & -3.548 & 1.871 & -0.109 & -1.897 & 0.050 & & \\
\hline Family planning & -3.945 & 4.986 & -0.051 & -0.791 & 0.429 & & \\
\hline Postpartum sexuality & -0.761 & 5.903 & -0.011 & -0.129 & 0.898 & & \\
\hline Sexually transmitted diseases & -7.017 & 8.123 & -0.064 & -0.864 & 0.388 & & \\
\hline Sexual dysfunctions & 0.457 & 3.881 & 0.008 & 0.118 & 0.906 & & \\
\hline \multicolumn{8}{|l|}{ Comfort in counseling } \\
\hline $\begin{array}{l}\text { Emotion experienced in case of } \\
\text { information request }\end{array}$ & -0.771 & 0.687 & -.060 & -1.122 & 0.263 & \multirow{4}{*}{$\begin{array}{l}R=0.194 \\
R^{2}=0.038\end{array}$} & \multirow{4}{*}{$\begin{array}{l}F=3.314 \\
p=0.011\end{array}$} \\
\hline $\begin{array}{l}\text { The person to be provided with } \\
\text { counseling }\end{array}$ & -0.891 & 1.228 & -.039 & -0.726 & 0.469 & & \\
\hline $\begin{array}{l}\text { Worries about reflecting their own } \\
\text { life }\end{array}$ & -0.207 & 0.913 & -0.012 & -0.227 & .821 & & \\
\hline Time of initiating counseling & -3.531 & 1.111 & -0.171 & -3.177 & 0.002 & & \\
\hline
\end{tabular}




\section{Discussion}

The results show that student midwives, who are closely related to pregnant women due to their fields of fundamental care, had medium-level negative attitudes and beliefs about sexuality during pregnancy. The presence of the attitudes and beliefs about sexuality during pregnancy was found to be associated with sexual counseling comfort. The comfort in sexual counseling increases with the decrease in negative attitudes and beliefs. This result supports the thought that an individual's values and experiences affect his/her attitudes towards sexual problems and that negative attitudes could affect effective sexual health consultation $(17,22)$. In this regard, assessment of students' knowledge about their own values, prejudices, and attitudes towards working on sexual health and raising awareness about their competence level about the way they handle problems is highly important (18-20).

In pregnancy process, maintaining the couple's sexual health, recognizing their worries, helping to solve them, and improving their sexual functions are part of the sexual counseling role of midwives. Knowledge and cultural doctrines acquired from the family among the factors shaping the attitudes were found to be effective factors that had effects on attitudes and beliefs about sexuality during pregnancy. However, these two factors were not associated with comfort in counseling. This condition does not seem to have negative effects on the comfort of counseling, which is promising. However, as stated by Krebs (18) and Papaharitou et al. (19), is it also worrying that feelings of comfort in midwives who have negative attitudes and beliefs during counseling might cause them to reflect their own values on the content of the service they provide.

As expected, class levels were found to be closely associated with the attitudes and beliefs during pregnancy in terms of defining the formation process of the theoretical background. Turgut and Golbasi (24) reported that the sexuality counseling education given to nursing students decreased but not eliminated the perceived barriers. The authors interpreted this finding as the lack of sharp changes in individuals who reach a certain level of mentality, which is in line with the findings of the present study. However, the surprising result in this variable is that it did not cause any significant differences in the comfort level of counseling. Ören et al. (25) similarly found no significant differences in third and fourth-year midwifery students' comfort of counseling. In their study conducted with senior nursing students, Erenel and Özdemir (26) reported that education was effective in enhancing sexual health care, but still, they had problems in initiating sexual healthcare. A study that involved students from different health professions reported that nurses demonstrated relatively more positive attitudes about sexual counseling, but still they had various affecting barriers (27). The level and content of the education received about sexual health probably vary by universities. Different from these studies, the present study involving students from four class levels found that the first-year students had similar discomfort levels with fourth-year students in providing sexual counseling, which indicates that only education was not an effective factor for the comfort of counseling. In this regard, it could be interesting to explore the underlying reasons for having similar findings in different studies involving different populations.

The results showed that having adequate knowledge about sexual counseling and experience of presenting this knowledge were effective predictors of the decrease in negative attitudes and beliefs in sexuality during pregnancy. Studies investigating the frequency of experience in the form of a professional level do not mention its relationship with the comfort of counseling $(28,29)$. A study conducted with midwifery students reported that $55.7 \%$ of the participants encountered a few women who required sexual counseling; however, the study did not mention the effect of the frequency of encountering such cases with the comfort level (25). Another study 
indicated that experience was an effective factor in attitudes towards sexual healthcare (30). In this study, all the participants were female, and the majority of the target care group was composed of females; this result is considered to be associated with gender. The literature indicates that health professionals providing service to same-gender was reported to feel more comfortable $(17,25,31)$. Results showed that start talking about sexuality was seen as taboo, even if concerns about gender have disappeared. Many of students think that sexuality should be discussed when initiated by patients, as similar studies in literature $(25,26,32)$.

Several beliefs and attitudes have effects on the identity that can develop and change by the effects of culture and society. People may sometimes ignore their attitudes and beliefs due to their professional identity. Hence, the present study, different from the related literature, focuses on this point. Some of students were not disturbed by the probability of reflecting their own sexual life while giving information about sexuality and thus reportedly think that this case could create an environment of confidence, which was interpreted as a positive behavior. Various studies report negative beliefs and attitudes of students about sexuality (22, 3234). However, these studies generally highlight the importance of safe sexual life and reproductive health education. The probability of transmitting these sexual myths/ dysfunctional attitudes/negative attitudes and beliefs to individuals who were provided care is generally ignored in these studies. The findings of the present study show that midwifery students have beliefs

\section{Conclusions}

The issue of sexuality is still a taboo in societies that protect their traditional connections. In addition, it might not be possible to fully change the cultural and social doctrines. Although education is a tool for a change, the probability of fully eliminating the beliefs and attitudes is generally impossible. Student midwives have negative attitudes and beliefs about sexuality about sexuality during pregnancy, and these could affect their counseling attitudes. Moreover, the strength of this study is that it mentions the probability of midwives' reflecting these attitudes to pregnant women while providing them with sexual counseling.

\section{Strengths and limitations of the study}

This study primarily contributes to the limited literature on the identification of the relationship between student midwives' attitudes and beliefs about sexuality during pregnancy and comfort in sexual counseling and the predictive factors for these. The scale of sexual attitudes and beliefs in pregnancy is unique to our culture, and this study is the first research to evaluate healthcare professionals. However, This study has some limitations. Firstly the study was conducted only conducted only with midwifery students. Nurses and doctors specialize in a specific field only after graduation. In this regard, they might not be fully knowledgeable about this specific topic during their education. For this reason, nursing students and medical students were not included in the study. Secondly, the participants were composed of only females. There are limitations about accepting male students to the midwifery departments in Turkey; the departments accept only female students. For this reason, the study results do not include findings about male midwives for international researchers. Finally, the data collection tool used for measuring the sexual counseling comfort level is reliable; however, it is not specific to pregnancy. The scale, which frequently mentions the concept of patient, could be a drawback since pregnancy is not defined as a disease.

during pregnancy. Moreover, some of these attitudes and beliefs are the predictors of counseling skills. Therefore, during the education process, identifying health students' attitudes and beliefs and helping them to become aware of these attitudes and beliefs is an important step in terms of not only individual but also social aspects of the issue of sexuality during pregnancy. The 
difference between the attitudes and beliefs of health professionals about sexuality during pregnancy should be decreased, and if possible eliminated. There is a need for an educational model that evaluates individual attitudes and beliefs while developing sexual counseling skills. The findings of the study will be a resource for the development of educational content and cognitive behavior models.

\section{Conflict of Interest}

The authors declared no conflicts of interest with respect to the authorship and/or publication of this article.

\section{Funding}

This study was not funded by any organization. 


\section{References}

1. World Health Organization. Defining sexual health: report of a technical consultation on sexual health, 28-31 January 2002, WHO Web site, 2006. [cited 2020 Jul 20] Available from: https://www.who.int/reproductivehealth/p ublications/sexual_health/defining_sexu al_health.pdf?ua=1.

2. Jamali $S$, Javadpour $S$, Alborzi $M$, Haghbeen M, Mosallanezhad Z. A study of men's sexuality and their attitude during their wives' pregnancy. J Clinical and Diagnostic Research. 2018; 12(5):24-8. doi: 10.7860/JCDR/2018/ 32004.11555.

3. Smith A, Lyons A, Ferris J, Richters J, Marian P, Shelley J, Simpson JM. Sexual and relationship satisfaction among heterosexual men and women: The importance of desired frequency of sex. $J$ Sex Marital Ther. 2011; 37(2):104-15. doi:10.1080/0092623X.2011.560531.

4. Gokyildiz S, Beji NK. The effects of pregnancy on sexual life. J Sex Marital Ther. 2005; 31(3):201-15. doi: 10.1080/00926230590513410.

5. Jawed-Wessel S, Herbenick $D$, Schick VJ, Fortenberry D, Cattelona G, Reece $M$. Development and validation of the maternal and partner sex during pregnancy scales. J Sex Marital Ther. 2016; 42(8): 681-701. doi:10.1080/ $0092623 X .2015 .1113587$.

6. Jawed-Wessel S, Sevick E. The impact of pregnancy and childbirth on sexual behaviors: a systematic review. J Sex Res. 2017;54(4-5):411-23. doi:10.1080/ 00224499.2016 .1274715$.

7. Nakić Radoš S, Soljačić Vraneš H, Šunjić M. Sexuality during pregnancy: What is important for sexual satisfaction in expectant fathers? J Sex Marital Ther. 2015;41(3):282-93. doi: 10.1080/ $0092623 X .2014 .889054$.

8. Beveridge JK, Vannier SA, Rosen NO. Fear-based reasons for not engaging in sexual activity during pregnancy: associations with sexual and relationship well-being. $J$ Psychosom Obstet
Gynecol.2018;39(2):138-45. doi:10.1080/ $0167482 X .2017 .1312334$.

9. Fok WY, Chan LY, Yuen PM. Sexual behavior and activity in Chinese pregnant women. Acta Obstet Gynecol Scan. 2005; 84(10):934-38. doi:10.1080/ j.0001-6349.2005.00743.x.

10. Liu HI, Hsu P, Chen KH. Sexual activity during pregnancy in Taiwan: A qualitative study. J Sex Med. 2013;1(2):54-61. doi: 10.1002/sm2.13.

11. Ribeiro MC, de Tubino Scanavino $M$, do Amaral MLSA, de Moraes Horta AL, Torloni MR. Beliefs about sexual activity during pregnancy: a systematic review of the literature. J Sex Marital Ther. 2017;43(8): 822-32. doi:10.1080/ $0092623 X .2017 .1305031$.

12. Vannier SA, Rosen NO. Sexual distress and sexual problems during pregnancy: associations with sexual and relationship satisfaction. J Sex Med. 2017;14:387-95. doi:10.1016/j.jsxm.2016.12.239.

13. Corbacioglu A, Bakir VL, Akbayir O, Cilesiz Goksedef BP, Akca A. The role of pregnancy awareness on female sexual function in early gestation. J Sex Med. 2012;9(7):1897-903. doi: 10.1111/j.1743 $-6109.2012 .02740 . x$.

14. Shojaa $M$, Jouybari L, Sanagoo A. The sexual activity during pregnancy among a group of Iranian women. Arch Gynecol Obstet. 2009;279(3):353-56. doi:10.1007/ s00404-008-0735-z.

15. American Nurses Association. 2015. Nursing: Scope and standards of practice. 3rd ed. Silver Spring, MD. ANA Web site 2015. [cited 2020 Nov 25] Available from: https://www.iupuc.edu/ health-sciences/files/Nursing-ScopeStan dards-3E.pdf.

16. International Confederation of Midwives. International definition of the midwife. ICM Web site 2017 [cited 2020 Nov 25] Available from: https://www. internationalmidwives.org/assets/files/de finitions-files/2018/06/eng-definition_of_t he_midwife-2017.pdf. 
17. Areskoug-Josefsson K, Gard G. Sexual health as a part of physiotherapy: The voices of physiotherapy students. Sex Disabil. 2015;33(4):513-32. doi: 10.1007 /s11195-015-9403-y.

18. Krebs LU. Sexual assessment: research and clinical. Nurs Clin North Am. 2007;42(4):515-29. doi: 10.1016/j.cnur. 2007.07.004.

19. Papaharitou S, Nakopoulou E, Moraitou $M$, Tsimtsiou Z, Konstantinidou E, Hatzichristou D. Exploring sexual attitudes of students in health professions. J Sex Med. 2008;5(6): 1308-16. doi:10.1111/j.1743-6109. 2008.00826.x.

20. Sung SC, Huang HC, Lin MH. Relationship between the knowledge, attitude, and self-efficacy on sexual health care for nursing students. J Prof Nurs. 2015;31(3):254-61. doi:10.1016/ j.profnurs. 2014.11.001.

21. Salcan E, Gokyildiz Surucu S. Development and psychometric evaluation of the attitudes and beliefs scale about sexuality during pregnancy. J Sex Marital Ther. 2020;46(5):435-46. doi:10.1080/0092623X.2020.1749741.

22. Reynolds KE, Magnan, MA. Nursing attitudes and beliefs toward human sexuality: Collaborative research promoting evidence-based practice. Clinic Nurse Spec. 2005;19(5):255-9.

23. Ayhan H, lyigun E, Tastan S, Coskun H. Turkish version of the reliability and validity study of the sexual attitudes and belief survey. Sex Disabil. 2010; 28(4): 287-96 doi: 10.1007/s11195-010-9157-5.

24. Turgut N, Gölbasi Z. Sexuality assessment knowledge, attitude, and skill of nursing students: an experimental study with control group. International Journal of Nursing Knowledge. 2016;28:123-30.

25. Ören B, Zengin N, Yazıcı S, Akıncı AÇ. Attitudes, beliefs and comfort levels of midwifery students regarding sexual counseling in Turkey. Midwifery. 2018; 56:152-7. doi:10.1016/j.midw.2017.10. 014.
26. Erenel AS, Ozdemir SÇ. Attitude and behaviors of senior nursing students in assessment of sexual health. Sex Disabil. 2020; 38: 503-14. doi:10.1007/ s11195-020-09642-3.

27. Areskoug-Josefsson K, Juuso P, Gard G, Rolander $B$, Larsson A. Health care students' attitudes toward addressing sexual health in their future profession: Validity and reliability of a questionnaire. Int J Sex Health. 2016; 28(3): 243-50. doi: 10.1080/19317611.2016.1199453.

28. Saunamäki N, Andersson $M$, Engström M. Discussing sexuality with patients: nurses' attitudes and beliefs. $J$ Adv Nurs. 2010; 66: 1308-16. doi:10.1111/j.13652648.2010.05260.x.

29. Ozan YD, Duman M, Çiçek Ö. Nursing students' experiences on assessing the sexuality of patients: mixed method study. Sex Disabil. 2019;37: 613-23. doi: 10.1007/s11195-019-09567-6.

30. Kim JH. Factors influencing barriers to addressing patients' sexual health among clinical nurse. Journal of Korean Academy of Adult Nursing. 2010;22:113-20.

31. Sibil T, Judith A, Johannes B, Susanne MG. Contraceptive counseling by gynecologists-which Issues are discussed and does gender play a role. $J$ Psychosom Obstet Gynaecol. 2007;28:13-9. doi:10.1080/ 01674820601096120.

32. Bal MD, Sahiner NC. Turkish nursing students' attitudes and beliefs regarding sexual health. Sex Disabil. 2015;33:223-31. doi: 10.1007/s11195014-9388-y.

33. Golbası Z, Evcili F, Eroglu K, Bircan H. Sexual Myths Scale [SMS]: development, validity and reliability in Turkey. Sex Disabil. 2016;34:75-87. doi: 10.1007/s11195-016-9430-3.

34. Yılmaz M, Karataş B. Opinions of student nurses on sexual myths; a phenomenological study. Sex Disabil. 2018;36:277-89. doi:10.1007/s11195018-9517-0. 